\title{
Carcinoma of the Eyelid TNM Finding v7
}

National Cancer Institute

\section{Source}

National Cancer Institute. Carcinoma of the Eyelid TNM Finding v7. NCI Thesaurus. Code C88557.

A finding about one or more characteristics of carcinoma of the eyelid, following the rules of the TNM AJCC V7 classification system. 